\title{
First record of margay (Leopardus wiedii) in cloud forest of
} Guatemala

\section{Primer registro de margay (Leopardus wiedii) en bosque nuboso de Guatemala}

\author{
José Fernando Moreira-Ramírez ${ }^{1,2 *}$, Rony García-Anleu, Gabriela Ponce-Santizo', and Melvin Mérida \\ ${ }^{1}$ Wildlife Conservation Society, Programa para Guatemala. Avenida 15 de marzo casa número 3, C. P. 17001. Flores, Petén, Guate- \\ mala. E-mail: jmoreira@wcs.org (JFM-R), rgarcia@wcs.org (RG-A), gponce@wcs.org (GP-S), mmerida@wcs.org (MM). \\ ${ }^{2}$ Asociación Guatemalteca de Mastozoólogos ASOGUAMA. 13 calle A 1-26 zona 2, C. P. 01002 . Guatemala City, Guatemala. \\ *Corresponding author
}

\begin{abstract}
The margay (Leopardus wiedii) is a small to medium-sized Neotropical felid classified as endangered in Guatemala. Non-invasive methods have been recommended to detect elusive species with nocturnal habits in tropical environments. In this work, we present the first photographic record of margay in the Mario Dary Rivera University Biotope for Quetzal Conservation, department of Baja Verapaz using camera traps. This record represents the highest altitude observation for this species in the cloud forests of Guatemala. We used 7 camera traps, 4 LeafRiver ${ }^{\mathrm{TM}}$ model C-1BU with Canon @) Sure Shot Owl camera, and 3 DeerCam (860 Park Lane, Park Falls WI 54551). The camera traps were installed for 16 consecutive days (February 21 to March 8, 2008), and programmed to take pictures and with the date and hour of each photo recorded automatically. With a total effort of 110 traps/night, we obtained one record of margay in one camera trap in a cloud forest, confirming the presence of this feline at $1,770 \mathrm{~m}$. This photographic record is the first confirmed evidence of the presence of margay in the cloud forest of the Mario Dary Rivera University Biotope for Quetzal Conservation, at $3.3 \mathrm{~km}$ southeast of the municipal town of Purulhá. We recommend the implementation of long-term monitoring programs within the area using camera traps, aiming to investigate elusive species with nocturnal-crepuscular habits to promote conservation strategies.
\end{abstract}

Key words: Altitude; camera trap; carnivore; felidae; record.

El margay (Leopardus wiedii) es un felino Neotropical de tamaño pequeño a mediano clasificado como en peligro de extinción en Guatemala. Para detectar especies sigilosas o de hábitos nocturnos en ambientes tropicales se ha recomendado utilizar métodos no invasivos. En este trabajo, presentamos el primer registro fotográfico de margay en el Biotopo Universitario Mario Dary Rivera para la Conservación del Quetzal, departamento de Baja Verapaz, utilizando trampas cámara. Este registro representa la observación a mayor altitud para esta especie en bosques nubosos de Guatemala. Utilizamos 7 trampas cámara, 4 LeafRiver ${ }^{\mathrm{TM}}$ modelo C-1BU con cámara Canon@ Sure Shot Owl y 3 DeerCam (860 Park Lane, Park Falls WI 54551). Las trampas cámara fueron instaladas durante 16 días consecutivos (21 de febrero al 8 de marzo de 2008$)$ y fueron programadas para obtener fotografías con la hora y fecha impresa. Con un esfuerzo total de 110 trampas/noche, obtuvimos un registro de margay en una trampa cámara en bosque nuboso, confirmando la presencia de este felino a 1,770 m. Este registro fotográfico es la primera evidencia confirmada de la presencia de margay en el bosque nuboso del Biotopo Universitario Mario Dary Rivera para la Conservación del Quetzal, a $3.3 \mathrm{~km}$ al sureste del poblado municipal de Purulhá. Recomendamos la implementación de programas de monitoreo a largo plazo utilizando trampas cámara dentro del área, con el objetivo de investigar especies esquivas con hábitos crepusculares, nocturnos, para promover estrategias de conservación.

Palabras clave: Altitud; carnívoro; Felidae; registro; trampa cámara.

(c) 2021 Asociación Mexicana de Mastozoología, www.mastozoologiamexicana.org

The margay or tigrillo (Leopardus wiedii; Schinz, 1821) is one of the five wild cat species inhabiting Guatemala (Reid 2009). The margay ranges from the tropical lowlands of México south through Central America and the Amazon basin to southern Brazil and Paraguay (Nowell and Jackson 1996). The margay is strongly associated with forest habitat/tree cover, from continuous forest to small forest fragments in savanna ecosystems, both evergreen and deciduous, and occasionally recorded outside forested areas (Nowell and Jackson 1996; de Oliveira 1998, 2011). Margays have morphological adaptations that make them excellent climbers, such as long tails that they use for balance and ankles that rotate up to $180^{\circ}$ (Hunter 2015).

This felid lives from sea level up to $1,500 \mathrm{~m}$ height but rarely has been recorded up to $3,000 \mathrm{~m}$ in the Andes (de Oliveira 1994; Espinosa et al. 2018). Previous photographic record for Guatemala in cloud forest was reported at 1,750 m (Mármol-Kattán et al. 2019). Due to its elusive characteristics, it is one of the most difficult animals to observe. For this reason, it is suggested the use of camera traps to document its presence, abundance, and distribution (Tobler et al. 2008; Vanderhoff et al. 2011). In Guatemala, the margay is classified in Category 2, risk of extinction, of the threatened species list by the Consejo Nacional de Áreas Protegidas (CONAP 2009). The International Union for the Conservation of Nature assess this cat as Near Threatened with a decreasing population trend (de Oliveira et al. 2015). The Convention on International Trade in Endangered Species of Wild Flora and Fauna (CITES 2020) lists the margay in Appendix I that includes the most endangered species. 
In Guatemala, the margay has been documented by photographic records in private natural reserves of the volcanic mountain range and Zacapa (Escobar-Anleu et al. 2017), Izabal (Escobar-Anleu 2019), Petén (Moreira-Ramírez et al. 2009, 2011), and Baja Verapaz (Mármol-Kattán et al. 2019). In order to advance in margay conservation strategies, we need evidence about its occurrence and thus define research and management policies. Here we present the first photographic record of margay in the Mario Dary Rivera University Biotope for Quetzal Conservation, being the first record higher than $1,750 \mathrm{~m}$ in a cloud forest of Guatemala. This reliable record will help to update the distributional range and conservation programs.

The Mario Dary Rivera University Biotope for Quetzal Conservation (BQ) is located in central Guatemala, northeast of Sierra Chuacús between the municipalities of Purulhá and Salamá, in Baja Verapaz department $\left(15^{\circ}\right.$ $12^{\prime} 47.45^{\prime \prime} \mathrm{N}, 90^{\circ} 13^{\prime} 2.21^{\prime \prime} \mathrm{W}$; Figure 1). Since 1976, BQ has been managed by the Center for Conservation Studies of the University of San Carlos de Guatemala. It includes 1,017 ha of cloud forest with a buffer zone of 5,241 ha and an altitude range between 1,500 and $2,348 \mathrm{~m}$. The average annual rainfall is $2,092 \mathrm{~mm}$, with January-April with the least precipitation. The annual average temperature is $18{ }^{\circ} \mathrm{C}$, with range between 14 and $20^{\circ} \mathrm{C}$. The average relative humidity ranges between 89.5 and $98.9 \%$. Average annual humidity is $93.9 \%$. Vegetation includes ferns, mosses, lichens, orchids that grow abundant on trees up to $30 \mathrm{~m}$ height such as Engelhardia guatemalensis, Magnolia guatemalensis, Quercus spp., and Dendropanax arboreus (Basterrechea 1999).

To evaluate the presence of mammals, we used 7 camera traps, 4 LeafRiver ${ }^{\mathrm{TM}}$ model $\mathrm{C}-1 \mathrm{BU}$ with Canon ${ }^{\circ}$ Sure Shot Owl camera, and 3 DeerCam (860 Park Lane, Park Falls WI 54551). We placed camera traps for 16 consecutive days (21 February to 8 March 2008). To avoid data loss, on the seventh day of sampling, we checked the camera traps, changing batteries and rolls. The location of camera traps was based on the presence of animal signs (e.g., tracks, scratches, caves) as indicators (Moreira-Ramírez et al. 2009). Camera traps were set up along the sides of interpretive trails and spaced 50 to $400 \mathrm{~m}$ apart. For the 2 models of

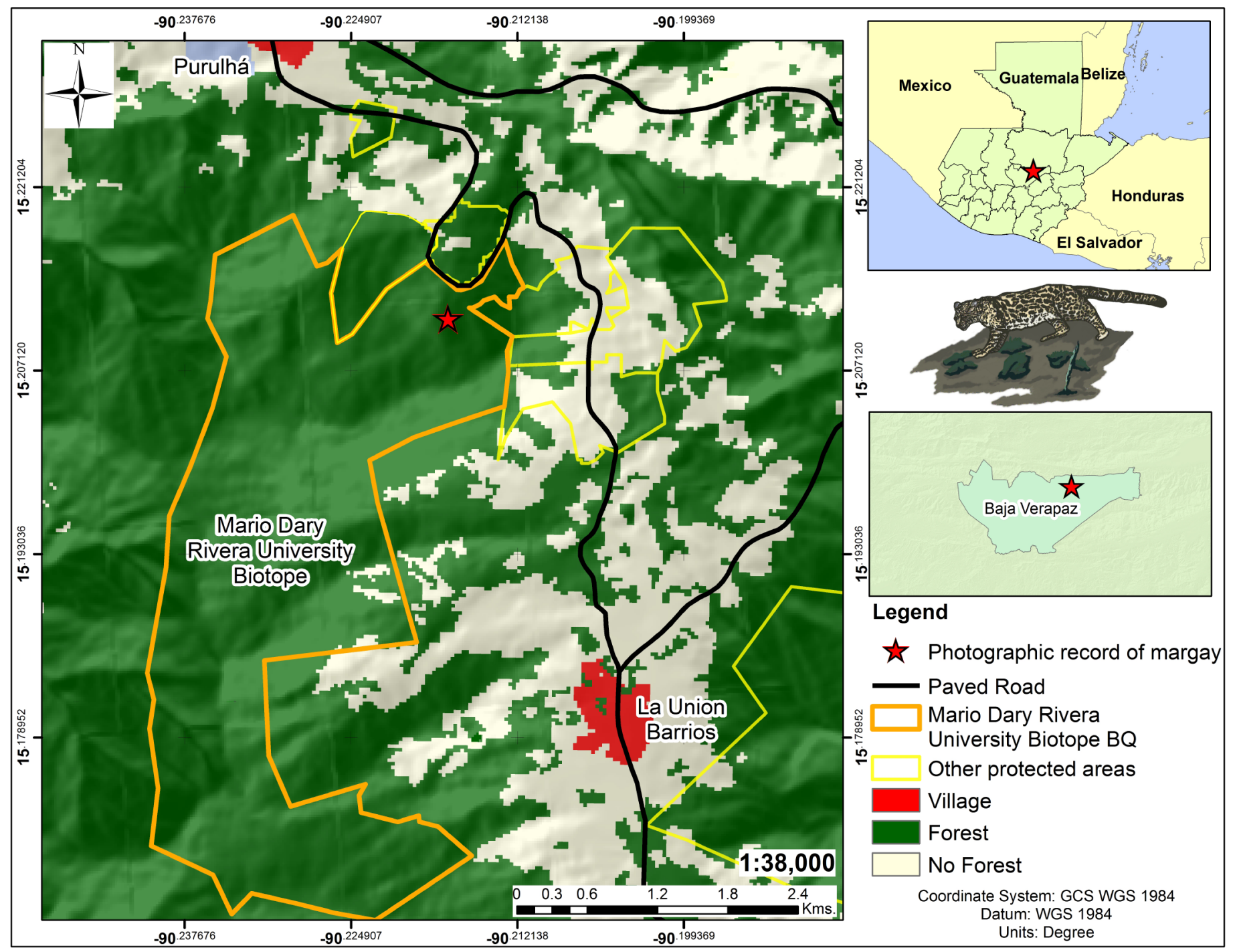

Figure 1. Map of the Mario Dary Rivera University Biotope for Quetzal Conservation, Baja Verapaz, Guatemala, showing the site of the margay photographic record (red star). 
camera traps, we used rolls of 24-print, 400 ASA $35-\mathrm{mm}$ film. The camera traps were set for 24-hour operation with a delay of one minute between consecutive photographs at a height of 30 to $40 \mathrm{~cm}$. The photographs were stored in the database of WCS Guatemala Program.

The total trapping effort was 110 trap/nights. During the sampling period, we photographed for the first time a margay in the $\mathrm{BQ}$. The record of margay was obtained in 1 camera trap at an altitude of $1,770 \mathrm{~m}\left(15^{\circ} 12^{\prime} 40.05^{\prime \prime} \mathrm{N}\right.$, $90^{\circ} 13^{\prime} 2.85^{\prime \prime} \mathrm{W}$ ) in the cloud forest, $3.3 \mathrm{~km}$ southeast of the municipal town of Purulhá, Baja Verapaz. The photographic record was obtained on February 26, 2008, at 23:41 hr (Figure 2). We identified the species based on the distinguishing features of margays: very large and bulging eyes, and very long tail measuring up to $70 \%$ of the head and body length and which is usually thick in appearance (de Oliveira 1998).

The margay is uncommon to rare throughout its range (de Oliveira et al. 2015). Our record of margay is important because it is the first record to confirm its presence in the $\mathrm{BQ}$, a protected area declared in 1976. It is also one of the few records in the cloud forest and the highest in Guatemala. Previously, there was no evidence in scientific litera- ture documenting the presence of this species in the $\mathrm{BQ}$ (Nagy-Reis et al. 2020; SNIBgt 2020), although comments from local rangers indicated a certain probability. This record confirms for the second time the presence of margay in Baja Verapaz department. Additional photographic records were obtained in the Ranchitos del Quetzal Natural Reserve between 2017 to 2019 at 1,680 - 1,750 m (MármolKattán et al. 2019). This nature reserve borders the north of the $\mathrm{BQ}$ and embraces a continuous protected cloud forest of approximately 1,300 ha. Our record confirms a new altitude for this species, obtained at $1,770 \mathrm{~m}$ in cloud forest, being higher than reported in 2019. In México, there are records of margays in cloud forests for the states of Guerrero, Jalisco, Morelos, Oaxaca, and San Luis Potosí, at elevations between 800 and 2,750 m (Aranda et al. 2012; Carvajal-Villarreal et al. 2012; Cinta-Magallón et al. 2012; Almazán-Catalán et al. 2013; Aranda and Valenzuela-Galván 2015). In Costa Rica and Colombia, this cat was documented at altitudes of 1,529 and 2,313 m, respectively (GonzálezMaya et al. 2018).

The margay is strongly associated with forest habitat/ tree cover, from continuous forest to small forest fragments (de Oliveira 2011), under moderate levels of habitat modi-

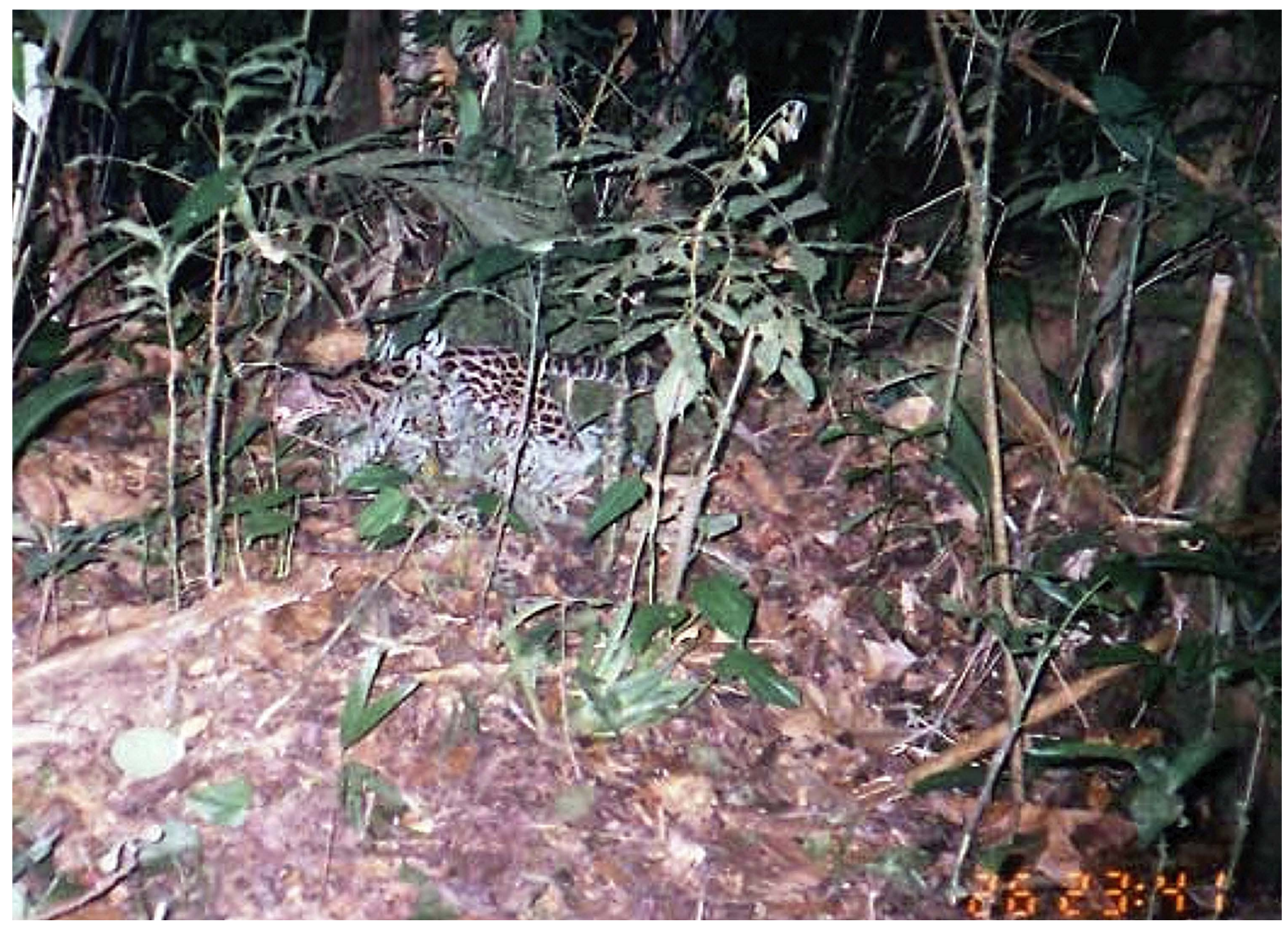

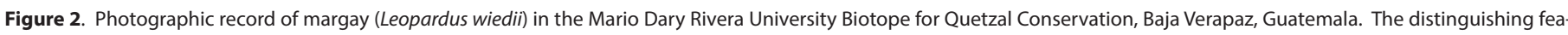
tures of margays include a very long tail measuring up to $70 \%$ of the head and body length. 
fication and human disturbance (Horn et al. 2020). The presence of margay suggests that the $\mathrm{BQ}$ still maintains habitat in good conservation status. We recommend the implementation of long-term monitoring programs within the $\mathrm{BQ}$ and adjacent protected areas aiming to investigate elusive species with nocturnal-crepuscular habits. This research tool will contribute to generating robust information and conservation strategies. Finally, we suggest evaluating margay as a possible conservation element for the $\mathrm{BQ}$.

\section{Acknowledgements}

We would like to thank the Center for Conservation Studies at the University of San Carlos de Guatemala (CECONUSAC), for allowing this research to be carried out within the $B Q$. We thank the $B Q$ park rangers for the interest shown during the camera trap workshop and field installation and review of camera traps. To the Wildlife Conservation Society and Jaguar Conservation Program, especially to R. McNab, J. Polisar, R. Salom, M. Córdova, F. Córdova, J. Tut, and M. Barnes for their support. We are grateful G. Castillo, R. Rivas, W. Martínez, and anonymous reviewers for their valuable comments.

\section{Literature cited}

Almazán-Catalán, J. A., C. Sánchez-Hernández, F. Ruiz-Gutiérrez, M. L. Romero-Almaraz, A. Taboada-Salgado, E. BeltránSánchez, AND L. Sánchez-VÁzquez. 2013. Registros adicionales de felinos del estado de Guerrero. Revista Mexicana de Biodiversidad 84:347-359.

Aranda, M., F. Botello, and L. López-De Buen. 2012. Diversidad y datos reproductivos de mamíferos medianos y grandes en el bosque mesófilo de montaña de la Reserva de la Biosfera Sierra de Manantlán, Jalisco-Colima, México. Revista Mexicana de Biodiversidad 83:778-784.

Aranda, M., and D. Valenzuela-Galván. 2015. Registro notable de margay (Leopardus wiedii) en el bosque mesófilo de montaña de Morelos, México. Revista Mexicana de Biodiversidad 86:1110-1112.

BasterrecheA, M. 1999. Plan Maestro 2000-2004. Biotopo Universitario "Mario Dary Rivera” para la Conservación del Quetzal. Asesoria Manuel Basterrechea Asociados. Centro de Estudios Conservacionistas (CECON), Universidad de San Carlos de Guatemala (USAC). Guatemala City, Guatemala. https:// conap.gob.gt/wp-content/uploads/2019/10/PM-BP-MarioDary-Rivera.pdf

Carvajal-Villarreal, S., A. Caso, P. Downey, A. Moreno, M. E. Tewes, AND L. I. Grassman JR. 2012. Spatial patterns of the margay (Leopardus wiedii; Felidae, Carnivora) at "El Cielo" Biosphere Reserve, Tamaulipas, Mexico. Mammalia 76:237-244.

Cinta-Magallón, C., C. Bonilla-Ruiz, R. Alarcón, and J. ArRoyo-Cabrales. 2012. Dos nuevos registros de margay (Leopardus wiedii) en Oaxaca, México, con datos sobre hábitos alimentarios. Research Journal of the Costa Rican Distance Education University 41:33-40.

Consejo Nacional de Áreas Protegidas (CONAP). 2009. Lista de Especies Amenazadas de Guatemala-LEA-. Second edition. Consejo Nacional de Áreas Protegidas. Agencia de Estados Unidos para el Desarrollo Internacional USAID. Guate- mala City, Guatemala. https://www.roavis.net/wp-content/ uploads/2018/07/8GTLista-de-Especies-LEA-GT.pdf

Convention on International Trade in Endangered Species of Wild Fauna and Flora (CITES). 2020. CITES https://www. cites.org/eng/app/index.php

de Oliveira, T. G. 1994. Neotropical cats: ecology and conservation. São Luís: Editora da Universidade Federal do Maranhão. Maranhão, Brazil.

De Oliveira, T. G. 1998. Leopardus wiedii. Mammalian Species 579:1-6.

DE Oliveira, T. G. 2011. Ecologia e conservação de pequenos felinos no Brasil e suas implicações para o manejo. Universidade Federal de Minas Gerais. Minas Gerais, Brazil.

de Oliveira, T. G., A. Paviolo, J. Schipper, R. Bianchi, E. Payan, and S. V. Carvajal. 2015. Leopardus wiedii. In: IUCN 2020. The IUCN Red List of Threatened Species. Version e.T11511A50654216. https://www.iucnredlist.org. Accesed June 5, 2020.

Escobar-Anleu, B., C. Fuentes-Montejo, and D. Ariano-Sánchez. 2017. Registros de mamíferos (Mammalia: Didelphimorphia, Artiodactyla, Carnivora, Cingulata, Lagomorpha, Pilosa y Rodentia) en reservas naturales privadas de Guatemala. Acta Zoológica Mexicana 33:389-393.

Escobar-Anleu, B. 2019. Panthera y la iniciativa del Corredor del Jaguar: el reto de conservar grandes felinos en un paisaje cambiante. Yu'am Revista Mesoamericana de Biodiversidad y Cambio Climático 3:55-60.

Espinosa, C. C., T. C. Trigo, F. P. Tirelli, L. G. da Silva, E. Eizirik, D. Queirolo, F. D. Mazim, F. B. Peters, M. O. Favarini, and T. R. DE Freitas. 2018. Geographic distribution modeling of the margay (Leopardus wiedii) and jaguarondi (Puma yagouaroundi): a comparative assessment. Journal of Mammalogy 99:252-262.

González-Maya, J. F., A. Arias-Alzate, R. Granados-Peña, D. A. Gómez-Hoyos, J. Schipper, M. Manjarrés-Morrón, and G. Manjarrés-Pinzón. 2018. Margays also hide their spots: First records of melanistic Leopardus wiedii from Colombia and Costa Rica. Revista Mexicana de Biodiversidad 89:587-589.

Horn, P. E., M. J. R. Pereira, T. C. Trigo, E. Eizirik, and F. P. TIRELlı. 2020. Margay (Leopardus wiedii) in the southern most Atlantic Forest: Density and activity patterns under different levels of anthropogenic disturbance. Plos One 15:e0232013. Hunter, L. 2015. Wild Cats of the World. Bloomsbury Natural History. London, United Kingdom.

Mármol-Kattán, A., G. Palomo-Muñoz, J. P. Pinto-Meneses, and I. Rosito-Prado. 2019. Registro notable de dos mesocarnívoros en el bosque nuboso de Baja Verapaz, Guatemala. Revista Mexicana de Mastozoología, nueva época 9:56-61.

Moreira-Ramírez, J. F., R. García-Anleu, R. McNab, G. PonceSantizo, M. Mérida, and G. Ruano. 2009. Abundancia de jaguares y evaluación de presas asociadas al fototrampeo en las concesiones comunitarias del bloque de Melchor de Mencos, Reserva de la Biosfera Maya, Petén, Guatemala. Informe Técnico. Wildlife Conservation Society, Programa Para Guatemala. Available at jmoreira@wcs.org.

Moreira-Ramírez, J. F., R. García-Anleu, R. McNab, G. Ruano, G. Ponce-Santizo, M. Mérida, K. Tut, P. Díaz, E. González, M. Córdova, E. Centeno, C. López, A. Vanegas, Y. Vanegas, F. Córdova, J. Kay, and M. Barnes. 2011. Abundancia de Jag- 
uares y Presas Asociadas al Fototrampeo en el sector oeste del Parque Nacional Mirador - Río Azul, Reserva de Biosfera Maya. Informe Técnico. Wildlife Conservation Society-Programa para Guatemala. Available at jmoreira@wcs.org.

Nagy-Reis, M., J. Oshima, C. Kanda, And et al. 2020. Neotropical Carnivores: a data set on carnivore distribution in the Neotropics. Ecology 101:e03128.

Nowell, K., And P. Jackson. 1996. Wild Cats. Status Survey and Conservation Action Plan. IUCN/SSC Cat Specialist Group. Gland, Switzerland and Cambridge, United Kingdom.

Reid, F. A. 2009. A field guide to the mammals of Central America and Southeast Mexico. Second edition. Oxford University Press. New York, U.S.A.

Sistema Nacional de Informacion sobre Diversidad Biológica de Guatemala (SNIBGt). 2020. SNIBgt Occurrence download at https://snib.conap.gob.gt/registros/occurrences/search $\mathrm{q}=$ Leopardus\%20wiedii. Accesed June 5, 2020.

Tobler, M. W., S. Carrillo-Percastegul, R. Leite Pitman, R. Mares, AND G. Powell. 2008. An evaluation of camera traps for inventorying large- and medium-sized terrestrial rainforest mammals. Animal Conservation 11:169-178.

Vanderhoff, N., A. Hodge, B. Arbogast, J. Nilsson, and T. KNowles. 2011. Abundance and activity patterns of the margay (Leopardus wiedii) at a mid-elevation site in the eastern Andes of Ecuador. Mastozoología Neotropical 18:271-279.

Associated editor: Nicté Ordoñez-Garza

Submitted: June 22, 2020; Reviewed: February 21, 2021.

Accepted: February 24, 2021; Published on line: March 8, 2021. 